\title{
Epidemiological Study of False Smut of Rice (Oryza sativa L.) in Gujarat, India
}

\author{
Ankit Kantibhai Chaudhari*, Kalubhai Balubhai Rakholiya \\ and Tushar Tersingbhai Baria
}

\author{
Department of Plant Pathology, N. M. College of Agriculture, \\ Navsari Agricultural University, Navsari-396 450 (Gujarat), India \\ *Corresponding author
}

\section{A B S T R A C T}

\section{Keywords}

Epidemiology, False smut, Rice, Correlation, Regression, Weather parameter

Article Info

Accepted:

20 May 2019

Available Online:

10 June 2019
Rice false smut [Ustilaginoidea virens (Cooke) Takahashi] is an upcoming major disease in India. The initiation of the disease was recorded the $88^{\text {th }}$ day after sowing and $9^{\text {th }}$ September in 2017 and $86^{\text {th }}$ day after sowing and $14^{\text {th }}$ September in 2018 . The incidence of false smut starts from 1.55 per cent at $36 \mathrm{MSW}$ and reached to 7.22 per cent at $42 \mathrm{MSW}$ in 2017 while, 0.53 per cent at $37 \mathrm{MSW}$ and reached to 6.68 per cent at $42 \mathrm{MSW}$ in 2018. However, in pooled of two years, the first symptom of false smut was recorded on 36 MSW $(0.77 \%)$ and reached to $42 \mathrm{MSW}(6.95 \%)$. Correlation coefficient study between weather parameters and disease incidence indicated that all the parameters jointly played an important role in the development of false smut disease. Moreover, maximum and average temperature, morning and average relative humidity, morning and average cloudy weather and sunshine hours were found to play important role in the disease development.Stepwise regression, R-value i.e., $0.89,0.80$ and 0.75 per cent and coefficient of determination, $\mathrm{R}^{2}$-value i.e., 79.90, 64.70 and 56.90 per cent were found high during 2017, 2018 and pooled of two year, respectively. These high R-value was indicated strong association between disease incidences to weather parameters.

\section{Introduction}

Rice false smut caused by Ustilaginoidea virens (Cooke) Takahashi and epidemically it was reported in Tamil Nadu in India and later in many countries of world (Singh and Pophaly, 2010). In recent years, rice false smut has become a serious problem in many parts of the world due to climate-change and growing high yielding rice varieties, which were more susceptible to diseases. The false smut occurs in more than 40 countries, including India (Dodan and Singh, 1996) and it has already changed from a minor disease to a major disease. $U$. virens overwinters by producing fungal structures called sclerotia, which contain chlamydospores (resting spores) and compact masses of mycelia (Fan et al., 2014 and Biswas, 2001). The fungus forms chlamydospores and sclerotia late in the season which fall in the soil and to survive for at least 4 months under field conditions in the winter. Sclerotia germinate to produce ascocarp containing ascospores, which are the act as a primary source of infection to rice plant, whereas chlamydospores are a 
secondary source of infection may come from airborne. During $U$. virens life cycle, produces sexual stage known as an ascospores, and asexual stage known as a chlamydospore, both stages play a very important role to initiated $U$. virens infection process (Biswas, 2001). False smut galls have been reported to emerge about 20 days after the initial infection of kernels of the rice panicle during the flowering of the rice plant. Infection results in one or more kernels on mature heads of plants being replaced by globose, yellowish-green, velvety smut balls. When smut balls burst open, powdery dark green spores are released (Atia, 2004).The rice false smut favouring the climatic factor is cloudy weather, high relative humidity (>95\%), low temperature $\left(25\right.$ to $\left.30^{\circ} \mathrm{C}\right)$, water stress and rainy days at the time of flowering (Raji et al., 2016 and Sanghera et al., 2012) and late sowing and application of higher nitrogen doses favours the development of disease (Ahonsi et al., 2000). Moreover, high relative humidity (89 to $95 \%$ ) and no rainfall were favourable for development of false smut in rice has also been reported (Devi and Singh 2007). Besides, optimum temperature (31.36 to $\left.23.14^{\circ} \mathrm{C}\right)$, high relative humidity (88.85 to $73.50 \%)$, least rainfall $(6.66 \mathrm{~mm})$ and bright sunshine hours $(6.20 \mathrm{hrs}$.) weather conditions were recorded more favourable for development of false smut in rice (Bhargava et al., 2018).In damp weather, the disease can be severe and losses can reach to 85 per cent has been reported from Tamil Nadu on different rice cultivars (Ladhalakshmi et al., 2012).Therefore, the present studies were done to know the effect of different weather parameter on the false smut disease incidence of rice.

(i) Per cent infected tillers

\section{Materials and Methods}

The experiment was conducted at N. M. College of Agriculture farm, NAU, Navsari, during kharif 2017 and kharif 2018.It's Latitude 200 57' 07.05" N, Longitude 720 $55^{\prime} 16.50 " \mathrm{E}$ and altitude is 12.33 meter above sea level.

Epidemiological study on the effect of weather parameters on the false smut disease of rice in the fixed plot was $20 \mathrm{~m} \times 20 \mathrm{~m}$ and at a distance of $20 \mathrm{~cm} \times 15 \mathrm{~cm}$ cultivar GR-11 was used. Two seedlings in each hill were planted. Fertilizers and other agronomical practices were followed according to the recommendations for growing high-yielding varieties. To determine the influence of various environmental factors on the development of rice false smut, the disease incidence data were correlated with different meteorological parameters viz., rainfall, maximum temperature (Max. T.), minimum temperature (Min. T.) relative humidity $(\mathrm{RH})$, wind velocity, cloudy weather, rainy days and sunshine hours through analysis of correlation and regression.

The weekly observations on false smut incidence were recorded throughout the season. Correlation and regression equation between disease incidence dependent factors were worked out using the standard procedure given by Gomez and Gomez (1984). The false smut disease incidence on cv. GR-11 was recorded as per the formula was given by Singh and Dube (1978).

Per cent disease incidence $=\quad \frac{\text { Total number of infected tillers } / \mathrm{m}^{2}}{\text { Total number of tillers } / \mathrm{m}^{2}} \times 100$ 


\section{Results and Discussion}

\section{Progress of false smut in cv. GR-11 under natural condition}

The observations on false smut incidence were recorded at a weekly interval in cv. GR11 at N. M. college farm, Navsari during the year of 2017 and 2018 which was presented in table 1, 2 and 3.

The first symptom of false smut was recorded $88^{\text {th }}$ days after sowing in susceptible variety GR-11. Which was sown on $12^{\text {th }}$ June of 2017 , transplanting on $7^{\text {th }}$ July 2017 and harvesting on $24^{\text {th }}$ October 2017. Since then, there was linear progress of the disease during the entire crop season. The main peak period of the false smut was recorded at $36 \mathrm{MSW}$ to 40 MSW (1.55 to 5.67\%) and reached at its highest on $21^{\text {st }}$ October of 42 MSW (7.22\%) during 2017. Whereas in 2018, first symptom of false smut was recorded after $86^{\text {th }}$ days after sowing in susceptible variety GR11. Which was sown on $18^{\text {th }}$ June of 2018 , transplanting on $13^{\text {th }}$ July 2018 and harvesting on $25^{\text {th }}$ October 2018. Since then, there was linear progress of the disease during the entire crop season. The main peak period of the false smut was recorded, at $37 \mathrm{MSW}$ to 40 MSW (0.53 to $4.81 \%)$ and reached at its highest on $26^{\text {th }}$ October of $42 \mathrm{MSW}(6.68 \%)$ in 2018. However, in pooled of two years first symptom of false smut was recorded at $36^{\text {th }}$ MSW in susceptible variety GR-11. Since then, there was linear progress of the disease during the entire crop season. The disease at the starting period $(0.77 \%)$ to reached $(6.95 \%)$.

Comparatively, false smut incidence was more during 2017 than in 2018. The weather during $33^{\text {rd }}$ to $35^{\text {th }}$ MSW played an important role in initiation of the false smut. During $39^{\text {th }}$ to $41^{\text {st }} \mathrm{MSW}$, there was very fast development of the disease due to congenial condition.
Hence, this period can be considered as a window period for the false smut of rice in Navsari condition. False smut infection starts from $36^{\text {th }}$ to $37^{\text {th }}$ MSW under favourable weather conditions. The infection on grain produced a huge quantity of inoculum in the presence of favourable climatic conditions, resulted yield loss. From the results of the present investigation, it is very clear that false smut of rice is very important and become a major disease in Navsari district. Hence, it causes heavy losses because, its infection starts at the flowering stage so, it directly effects on yield.

\section{Correlation of false smut incidence with weather parameters}

The disease started appearing at ripening stage of the crop and epidemiological studies were performed right upto harvesting of the crop. The false smut infection in susceptible cv. GR-11 and corresponding weather parameters at weekly interval were recorded which was presented in table 4.

During 2017, false smut was initiated on $36^{\text {th }}$ MSW. Previous two weeks $34^{\text {th }}$ and $35^{\text {th }}$ MSW were recorded maximum temperature i.e., 29.4 and $29.3^{\circ} \mathrm{C}$, average temperature i.e., 27.0 and $26.7^{\circ} \mathrm{C}$, morning relative humidity i.e., 94.6 and 96.6 per cent and bright sunshine hours i.e., 3.3 and 3.2 hrs., respectively. These conditions favoured for initiation of the false smut during flowering stage. More dominant favourable weather conditions viz., maximum temperature i.e., $31.4,34.0$ and $31.4^{\circ} \mathrm{C}$, average temperature i.e., 28.0, 29.6 and $27.6^{\circ} \mathrm{C}$, morning relative humidity i.e., 95.6, 91.3 and 96.5 per cent and bright sunshine hours i.e., 5.2, 4.7 and $2.1 \mathrm{hrs}$. lead to more progress of the disease during $36^{\text {th }}, 37^{\text {th }}$ and $38^{\text {th }}$ MSW, respectively. There was a continuously increased of the false smut during $36^{\text {th }}$ to $38^{\text {th }} \mathrm{MSW}$ in the presence of the warm and humid weather which 
considered a window period for the false smut of rice. After $38^{\text {th }}$ MSW upto harvest, the disease incidence was continuously increased and recorded upto 7.22 per cent disease incidence. Correlation matrix worked out showed that rainfall $(-0.367)$, minimum temperature (-0.378), evening relative humidity $(-0.425)$, average relative humidity $(-0.288)$ and rainy days $(-0.386)$ were found negatively correlated while, wind velocity (0.549 ) was found significantly and negatively correlated whereas, cloudy weather at morning, evening and average i.e., -0.653, 0.595 and -0.629 were found highly significantly and negatively correlated with the false smut incidence, respectively. Moreover, maximum temperature (0.704) was found highly significant and positive correlated while, average temperature $(0.477)$ was found significantly and positively correlated. Whereas, morning relative humidity (0.309) and bright sun-shine hours (0.285) were found non-significantly and positively correlated with the false smut incidence. Maximum temperature, average temperature and morning relative humidity were playing an important role in the disease development compared to other weather parameters.

More or less similar trends were recorded during the subsequent year in the progress of the false smut due to closely similar weather. In 2018, the disease was initiated on $37^{\text {th }}$ MSW. Previous two weeks $35^{\text {th }}$ and $36^{\text {th }}$ MSW were recorded maximum temperature i.e., 29.9 and $29.7^{\circ} \mathrm{C}$, average temperature i.e., 26.7 and $26.0^{\circ} \mathrm{C}$, morning relative humidity i.e., 92.6 and 90.1 per cent and bright sunshine hours i.e., 2.3 and 5.0 hrs., respectively. These conditions favoured for initiation of the false smut during flowering stage. More dominant favourable weather conditions viz., maximum temperature i.e., $30.8, \quad 32.7, \quad 33.8$ and $36.9^{\circ} \mathrm{C}$, average temperature i.e., $26.3,27.3,27.7$ and $29.8^{\circ} \mathrm{C}$ and bright sunshine hours i.e., 6.8, 6.8, 8.1 and $8.6 \mathrm{hrs}$. lead to more progress of the disease during $37^{\text {th }}, 38^{\text {th }}, 39^{\text {th }}$ and $40^{\text {th }}$ MSW, respectively. There was a sudden jump of the false smut during $37^{\text {th }}$ to $40^{\text {th }} \mathrm{MSW}$ in the presence of the warm and humid weather with bright sunshine which considered a window period for the false smut of rice. After $40^{\text {th }}$ MSW upto harvest, the disease incidence was continuously increased and recorded upto 6.68 per cent disease incidence. Correlation matrix worked out showed that rainfall (0.275), minimum temperature (-0.382), morning relative humidity $(-0.411)$, and rainy days (-0.475) were found negatively correlated while, wind velocity $(-0.511)$ was found significantly and negatively correlated with the false smut incidence. Whereas, evening relative humidity, average relative humidity, morning cloudy weather, evening cloudy weather and average cloudy weather i.e., $-0.625,-0.649,-0.760,-0.786$ and -0.804 were found highly significantly and negatively correlated with the false smut incidence, respectively. Moreover, maximum temperature (0.717) and bright sun-shine hours (0.649) were found highly significant and positive correlated, while average temperature (0.461) was found significant and positive correlated with the false smut incidence. Maximum temperature, average temperature and sunshine hours were playing an important role in the disease development compared to other weather parameters.

It is very clear from the results of two years that the false smut become a rising problem in Navsari district because of the presence of a pathogen, growing susceptible cv. GR-11 in most of the area and prevalence of congenial weather conditions. During mean of two years, maximum temperature i.e., 29.4 and $30.1^{\circ} \mathrm{C}$, average temperature i.e., 26.4 and $26.7^{\circ} \mathrm{Cand}$ bright sunshine hours i.e., 2.7 and $2.8 \mathrm{hrs}$. are more favourable for the progress of the false smut during $34^{\text {th }}$ and $35^{\text {th }}$ MSW, 
respectively. These conditions favoured for initiation of the false smut disease during flowering stage. More dominant favourable weather conditions viz., maximum temperature i.e., $31.5,32.3$ and $32.8^{\circ} \mathrm{C}$, average temperature i.e., 27.0, 28.0 and $27.4^{\circ} \mathrm{C}$ and bright sunshine hours i.e., 5.1, 5.8 and $4.5 \mathrm{hrs}$. are very crucial for the disease initiation during $36^{\text {th }}, 37^{\text {th }}$ and $38^{\text {th }} \mathrm{MSW}$, respectively. Moreover, disease fast progress during $39^{\text {th }}$ to $40^{\text {th }}$ MSW. However, the progress of the disease was slower during $41^{\text {st }}$ to $42^{\text {nd }} \mathrm{MSW}$ as compared to the previous weeks. The crop before ripening period remains free from the false smut infection. Correlation matrix worked out showed that rainfall (-0.297), minimum temperature ($0.308)$ and morning relative humidity $(-0.083)$ were found negatively correlated while, evening relative humidity (-0.544), average relative humidity $(-0.462)$, wind velocity ($0.518)$, morning cloudy weather (-0.683), evening cloudy weather (-0.645), average cloudy weather (-0.684) and rainy days (0.418) were found highly significantly and negatively correlated with the false smut incidence. Moreover, maximum temperature (0.695), average temperature (0.464) and bright sun-shine hours $(0.475)$ were found highly significant and positive correlated with the false smut incidence. Maximum temperature, average temperature and sunshine hours were playing a greater role in the disease development compared to other weather parameters.

\section{Stepwise regression equation for rice false smut on different weather parameters at Navsari}

The regression coefficient based on stepwise regression analysis for per cent false smut incidence of rice with respect to weather parameters have been worked out and presented in table 5, 6 and 7.
The result presented in table 5 indicated, stepwise regression, it has been also observed that R-value was high $(0.89 \%)$ indicating a strong association between per cent disease incidence to maximum temperature, average relative humidity and morning cloudy weather. The co-efficient of determination value was found to be 79.90 per cent. This clearly indicates that at least 89 per cent of variation in false smut incidence can be explained by the function of the weather parameter viz., maximum temperature, average relative humidity and morning cloudy weather during 2017.

The result presented in table 6 indicated, stepwise regression, it has been also observed that R-value was high $(0.80 \%)$ indicating a strong association between per cent disease incidence and average cloudy weather. The co-efficient of determination value was found to be 64.70 per cent. This clearly indicates that at least 80 per cent of the variation in false smut incidence can be explained by the function of the weather parameter viz., average cloudy weather during 2018.

The result presented in table 7 indicated, stepwise regression, it has been also observed that R-value was high $(0.75 \%)$ indicating a strong association between per cent disease incidence to maximum temperature and morning relative humidity. The co-efficient of determination value was found to be 56.90 per cent. This clearly indicates that at least 75 per cent of variation in false smut incidence can be explained by the function of the weather parameter viz., maximum temperature and morning relative humidity during pooled of two years.

Thus, observed false smut incidence and predicted false smut incidence found closely related and regression equation established may be most reliable and useful for forecasting of the rice false smut disease. The 
loss caused by the false smut can be saved by forewarning to the farmers and thereby controlling the same at the proper time.

The result was support with many workers. Hegde et al., (2000) conducted field experiment during kharif1996-97 in Karnataka and noticed that weather parameters i.e., maximum temperature $\left(<31^{\circ} \mathrm{C}\right)$ and low rainfall $(<5 \mathrm{~mm})$ during 50 per cent flowering was foundto be favourable and significantly effect on false smut development in rice. Devi and Singh (2007)found that high relative humidity (89 to $95 \%$ ) and no rainfall at milking stage to be favourable for false smut development in rice.

Table.1 Epidemiological study of false smut of rice in field condition during kharif 2017

\begin{tabular}{|c|c|c|c|c|c|c|c|c|c|c|c|c|c|c|}
\hline \multirow[t]{2}{*}{ MSW } & \multirow[t]{2}{*}{$\begin{array}{c}\text { Rainfall } \\
(\mathbf{m m})\end{array}$} & \multicolumn{3}{|c|}{$\begin{array}{c}\text { Temperature } \\
\left({ }^{\circ} \mathbf{C}\right)\end{array}$} & \multicolumn{3}{|c|}{$\begin{array}{l}\text { Relative Humidity } \\
\qquad(\%)\end{array}$} & \multirow{2}{*}{$\begin{array}{l}\text { Wind } \\
\text { Velocity } \\
(\mathbf{k m} / \mathbf{h r})\end{array}$} & \multicolumn{3}{|c|}{$\begin{array}{l}\text { Cloudy } \\
\text { Weather } \\
\text { (Octa) }\end{array}$} & \multirow[t]{2}{*}{$\begin{array}{c}\text { Rainy } \\
\text { Days }\end{array}$} & \multirow[t]{2}{*}{$\begin{array}{c}\text { BSSH } \\
\text { (hrs) }\end{array}$} & \multirow[t]{2}{*}{$\begin{array}{l}\text { PDI } \\
(\%)\end{array}$} \\
\hline & & Max & Min & $\mathbf{A v}$ & I & II & $\mathbf{A v}$ & & I & II & Av & & & \\
\hline 24 & 40 & 32.6 & 25.4 & 29.0 & 92.2 & 72.7 & 82.5 & 0.0 & 3 & 3 & 3 & 4 & 6.7 & 0.0 \\
\hline 25 & 12 & 33.7 & 27.2 & 30.5 & 84.6 & 71.0 & 77.8 & 0.0 & 4 & 3 & 4 & 2 & 8.0 & 0.0 \\
\hline 26 & 221 & 30.0 & 24.5 & 27.3 & 95.9 & 89.5 & 92.7 & 0.0 & 6 & 5 & 6 & 6 & 1.3 & 0.0 \\
\hline 27 & 35 & 1.3 & 26.2 & 28.7 & 8.3 & 76.6 & 82.4 & 0.0 & 3 & 3 & 3 & 3 & 3.6 & 0.0 \\
\hline 28 & 29 & 31.4 & 25.4 & 28.4 & 88.6 & 79.0 & 83.8 & 0.0 & 5 & 3 & 4 & 5 & 5.0 & 0.0 \\
\hline 29 & 330 & 29.2 & 24.5 & 26.8 & 98.6 & 89.1 & 93.8 & 0.0 & 7 & 5 & 6 & 7 & 2.0 & 0.0 \\
\hline 30 & 1 & .0 & 25.2 & 27.1 & 2.9 & 90.6 & 91.1 & 0.0 & 7 & 7 & 7 & 6 & 0.1 & 0.0 \\
\hline 31 & 57 & 30.0 & 25.1 & 27.6 & 84.2 & 79.2 & 81.7 & 0.0 & 4 & 4 & 4 & 5 & 4.2 & 0.0 \\
\hline 32 & 22 & 30.9 & 25.2 & 28.1 & 91.6 & 76.7 & 84.2 & 0.0 & 4 & 4 & 4 & 0 & 4.6 & 0.0 \\
\hline 33 & 10 & 31.3 & 25.5 & 28.4 & 90.5 & 75.6 & 83.1 & 0.0 & 5 & 3 & 4 & 1 & 6.2 & 0.0 \\
\hline 34 & 90 & .4 & 24.6 & 27.0 & .6 & 86.8 & 90.7 & 0.0 & 4 & 4 & 4 & 5 & 3.3 & 0.0 \\
\hline 35 & 177 & 29.3 & 24.1 & 26.7 & 96.6 & 86.2 & 91.4 & 0.0 & 6 & 5 & 5 & 6 & 3.2 & 0.0 \\
\hline 36 & 3 & 31.4 & 24.7 & 28.0 & 95.6 & 75.7 & 85.7 & 1.55 & 1 & 1 & 1 & 0 & 5.2 & 1.55 \\
\hline 37 & 2 & 34.0 & 25.1 & 29.6 & 91.3 & 75.0 & 83.1 & 2.58 & 3 & 1 & 2 & 0 & 4.7 & 2.58 \\
\hline 38 & 69 & 31.4 & 23.7 & 27.6 & 96.5 & 79.4 & 87.9 & 3.61 & 3 & 4 & 4 & 4 & 2.1 & 3.61 \\
\hline 39 & 0 & 33.3 & 23.8 & 28.6 & 94.1 & 65.5 & 79.8 & 4.64 & 0 & 1 & 1 & 0 & 7.3 & 3.87 \\
\hline 40 & 0 & 36.7 & 24.2 & 30.4 & 96.4 & 51.0 & 73.7 & 5.67 & 0 & 0 & 0 & 0 & 8.4 & 5.67 \\
\hline 41 & 28 & 4.4 & 23.7 & 29.0 & 93.9 & 68.7 & 81.3 & 6.70 & 2 & 2 & 2 & 4 & 4.3 & 6.70 \\
\hline 42 & 0 & 35.9 & 22.3 & 29.1 & 92.8 & 72.0 & 82.4 & 7.22 & 0 & 0 & 0 & 0 & 7.2 & 7.22 \\
\hline
\end{tabular}


Table.2 Epidemiological study of false smut of rice in field condition during kharif 2018

\begin{tabular}{|c|c|c|c|c|c|c|c|c|c|c|c|c|c|c|}
\hline \multirow[t]{2}{*}{ MSW } & \multirow[t]{2}{*}{$\begin{array}{c}\text { Rainfall } \\
(\mathrm{mm})\end{array}$} & \multicolumn{3}{|c|}{$\begin{array}{c}\text { Temperature } \\
\left({ }^{\circ} \mathbf{C}\right)\end{array}$} & \multicolumn{3}{|c|}{$\begin{array}{c}\text { Relative Humidity } \\
(\%)\end{array}$} & \multirow[t]{2}{*}{$\begin{array}{c}\text { Wind } \\
\text { Velocity } \\
\text { (km/hr) }\end{array}$} & \multicolumn{3}{|c|}{$\begin{array}{c}\text { Cloudy } \\
\text { Weather } \\
\text { (Octa) }\end{array}$} & \multirow[t]{2}{*}{$\begin{array}{l}\text { Rainy } \\
\text { Days }\end{array}$} & \multirow[t]{2}{*}{$\begin{array}{c}\text { BSSH } \\
(\mathrm{hrs})\end{array}$} & \multirow[t]{2}{*}{$\begin{array}{l}\text { PDI } \\
(\%)\end{array}$} \\
\hline & & Max & Min & $\mathbf{A v}$ & I & II & Av & & I & II & $\mathbf{A v}$ & & & \\
\hline 25 & 1 & 33.4 & 25.9 & 29.7 & 86.9 & 71.9 & 79.4 & 0.0 & 7 & 5 & 6 & 0 & 6.0 & 0.0 \\
\hline 26 & 67 & 31.3 & 24.6 & 28.0 & 95.9 & 78.3 & 87.1 & 0.0 & 6 & 6 & 6 & 3 & 3.7 & 0.0 \\
\hline 27 & 340 & 30.7 & 23.9 & 27.3 & 98.7 & 94.3 & 96.5 & 0.0 & 8 & 7 & 7 & 6 & 3.0 & 0.0 \\
\hline 28 & 619 & 28.1 & 23.1 & 25.6 & 99.5 & 97.3 & 98.4 & 0.0 & 8 & 8 & 8 & 7 & 0.0 & 0.0 \\
\hline 29 & 314 & 26.8 & 23.3 & 25.1 & 98.5 & 97.3 & 97.9 & 0.0 & 8 & 8 & 8 & 7 & 0.0 & 0.0 \\
\hline 30 & 9 & 29.1 & 25.0 & 27.1 & 89.2 & 85.9 & 87.6 & 0.0 & 8 & 8 & 8 & 2 & 0.2 & 0.0 \\
\hline 31 & 4 & 30.3 & 25.0 & 27.7 & 80.3 & 81.1 & 80.7 & 0.0 & 6 & 7 & 7 & 0 & 1.0 & 0.0 \\
\hline 32 & 11 & 30.0 & 24.7 & 27.4 & 91.6 & 81.3 & 86.4 & 0.0 & 8 & 8 & 8 & 2 & 1.5 & 0.0 \\
\hline 33 & 53 & 29.7 & 23.8 & 26.8 & 92.7 & 83.7 & 88.2 & 0.0 & 8 & 8 & 8 & 5 & 0.6 & 0.0 \\
\hline 34 & 127 & 29.0 & 22.8 & 25.9 & 98.8 & 85.2 & 92.0 & 0.0 & 8 & 8 & 8 & 7 & 2.1 & 0.0 \\
\hline 35 & 27 & 29.9 & 23.5 & 26.7 & 92.6 & 77.9 & 85.3 & 0.0 & 8 & 7 & 7 & 3 & 2.3 & 0.0 \\
\hline 36 & 35 & 29.7 & 22.2 & 26.0 & 90.1 & 73.3 & 81.7 & 0.0 & 6 & 6 & 6 & 2 & 5.0 & 0.0 \\
\hline 37 & 1 & 30.8 & 21.8 & 26.3 & 89.9 & 69.7 & 79.8 & 0.53 & 5 & 7 & 6 & 0 & 6.8 & 0.53 \\
\hline 38 & 15 & 32.7 & 21.8 & 27.3 & 90.6 & 60.1 & 75.3 & 1.60 & 1 & 4 & 3 & 1 & 6.8 & 1.60 \\
\hline 39 & 0 & 33.8 & 21.5 & 27.7 & 90.9 & 50.0 & 70.5 & 3.21 & 0 & 2 & 1 & 0 & 8.1 & 3.21 \\
\hline 40 & 0 & 36.9 & 22.7 & 29.8 & 82.9 & 48.6 & 65.7 & 4.81 & 1 & 0 & 1 & 0 & 8.6 & 4.81 \\
\hline 41 & 0 & 36.8 & 21.9 & 29.4 & 88.6 & 52.9 & 70.8 & 5.88 & 1 & 0 & 0 & 0 & 8.4 & 5.88 \\
\hline 42 & 0 & 36.4 & 20.3 & 28.3 & 81.6 & 58.0 & 69.8 & 6.68 & 0 & 1 & 0 & 0 & 8.5 & 6.68 \\
\hline
\end{tabular}

* MSW- Meteorological standard week, BSSH- Bright sun-shine hours, PDI- Per cent disease incidence 
Table.3 Epidemiological study of false smut of rice in field condition during pooled of two years

\begin{tabular}{|c|c|c|c|c|c|c|c|c|c|c|c|c|c|c|}
\hline \multirow[t]{2}{*}{ MSW } & \multirow[t]{2}{*}{$\begin{array}{c}\text { Rainfall } \\
(\mathbf{m m})\end{array}$} & \multicolumn{3}{|c|}{$\begin{array}{c}\text { Temperature } \\
\left({ }^{\circ} \mathbf{C}\right)\end{array}$} & \multicolumn{3}{|c|}{$\begin{array}{c}\text { Relative Humidity } \\
(\%)\end{array}$} & \multirow[t]{2}{*}{$\begin{array}{c}\text { Wind } \\
\text { Velocity } \\
\text { (km/hr) }\end{array}$} & \multicolumn{3}{|c|}{$\begin{array}{c}\text { Cloudy } \\
\text { Weather } \\
\text { (Octa) }\end{array}$} & \multirow[t]{2}{*}{$\begin{array}{l}\text { Rainy } \\
\text { Days }\end{array}$} & \multirow[t]{2}{*}{$\begin{array}{r}\text { BSSH } \\
\text { (hrs) }\end{array}$} & \multirow[t]{2}{*}{$\begin{array}{l}\text { PDI } \\
(\%)\end{array}$} \\
\hline & & Max & Min & Av & I & II & Av & & I & II & Av & & & \\
\hline 24 & 22 & 33.4 & 26.3 & 29.8 & 91.5 & 75.2 & 83.4 & 8.8 & 5 & 5 & 5 & 3 & 5.4 & 0.0 \\
\hline 25 & 6.5 & 32.1 & 26.6 & 30.1 & 85.8 & 71.5 & 78.6 & 8.5 & 5 & 4 & 5 & 1 & 7.0 & 0.0 \\
\hline 26 & 143.8 & 30.8 & 24.6 & 27.6 & 95.9 & 83.9 & 89.9 & 8.1 & 6 & 6 & 6 & 5 & 2.5 & 0.0 \\
\hline 27 & 187.5 & 30.4 & 25.1 & 28.0 & 93.5 & 85.4 & 89.5 & 8.5 & 6 & 5 & 5 & 5 & 3.3 & 0.0 \\
\hline 28 & 325.5 & 28.9 & 24.3 & 27.0 & 94.1 & 88.1 & 91.1 & 6.7 & 6 & 6 & 6 & 5 & 2.5 & 0.0 \\
\hline 29 & 322 & 28.5 & 23.9 & 25.9 & 98.5 & 93.2 & 95.9 & 5.7 & 7 & 7 & 7 & 7 & 1.0 & 0.0 \\
\hline 30 & 80.5 & 29.6 & 25.1 & 27.1 & 91.0 & 88.3 & 89.6 & 8.3 & 7 & 7 & 7 & 4 & 0.2 & 0.0 \\
\hline 31 & 30.3 & 30.3 & 25.1 & 27.6 & 82.3 & 80.2 & 81.2 & 19.7 & 5 & 6 & 5 & 3 & 2.6 & 0.0 \\
\hline 32 & 16.5 & 30.5 & 24.9 & 27.7 & 91.6 & 79.0 & 85.3 & 7.3 & 6 & 6 & 6 & 1 & 3.0 & 0.0 \\
\hline 33 & 31.5 & 29.8 & 24.7 & 27.6 & 91.6 & 79.6 & 85.6 & 6.7 & 7 & 5 & 6 & 3 & 3.4 & 0.0 \\
\hline 34 & 108.5 & 29.4 & 23.7 & 26.4 & 96.7 & 86.0 & 91.3 & 5.3 & 6 & 6 & 6 & 6 & 2.7 & 0.0 \\
\hline 35 & 102 & 30.1 & 23.8 & 26.7 & 94.6 & 82.0 & 88.3 & 4.6 & 7 & 6 & 6 & 5 & 2.8 & 0.0 \\
\hline 36 & 19 & 31.5 & 23.5 & 27.0 & 92.9 & 74.5 & 83.7 & 4.1 & 3 & 4 & 3 & 1 & 5.1 & 0.77 \\
\hline 37 & 1.5 & 32.3 & 23.5 & 28.0 & 90.6 & 72.3 & 81.5 & 2.9 & 4 & 4 & 4 & 0 & 5.8 & 1.56 \\
\hline 38 & 42 & 32.8 & 22.8 & 27.4 & 93.6 & 69.7 & 81.6 & 2.9 & 2 & 4 & 3 & 3 & 4.5 & 2.61 \\
\hline 39 & 0 & 35.2 & 22.7 & 28.1 & 92.5 & 57.8 & 75.2 & 2.2 & 0 & 2 & 1 & 0 & 7.7 & 3.54 \\
\hline 40 & 0 & 36.2 & 23.4 & 30.1 & 89.6 & 49.8 & 69.7 & 2.2 & 1 & 0 & 0 & 0 & 8.5 & 5.24 \\
\hline 41 & 14 & 35.9 & 22.8 & 29.2 & 91.3 & 60.8 & 76.0 & 2.3 & 1 & 1 & 1 & 2 & 6.3 & 6.29 \\
\hline 42 & 0 & 36.1 & 21.3 & 28.7 & 87.2 & 65.0 & 76.1 & 1.7 & 0 & 0 & 0 & 0 & 7.9 & 6.95 \\
\hline
\end{tabular}

* MSW- Meteorological standard week, BSSH- Bright sun-shine hours, PDI- Per cent disease incidence 
Table.4 Correlation of per cent disease incidence with weather parameters during experimentation

\begin{tabular}{|c|l|c|c|c|}
\hline \multirow{2}{*}{ Sr. No. } & Weather Parameters & \multicolumn{3}{|c|}{ Correlation } \\
\cline { 3 - 5 } & & $\mathbf{2 0 1 7}$ & $\mathbf{2 0 1 8}$ & \multicolumn{1}{|c|}{ Pooled } \\
\hline $\mathbf{1}$ & Rainfall & -0.367 & -0.275 & -0.297 \\
\hline $\mathbf{2}$ & Temperature Maximum & $0.704 * *$ & $0.717 * *$ & $0.695 * *$ \\
\hline $\mathbf{3}$ & Temperature Minimum & -0.378 & -0.382 & -0.308 \\
\hline $\mathbf{4}$ & Temperature Average & $0.477 *$ & $0.461 *$ & $0.464 * *$ \\
\hline $\mathbf{5}$ & Relative Humidity Morning & 0.309 & -0.411 & -0.083 \\
\hline $\mathbf{6}$ & Relative Humidity Evening & -0.425 & $-0.625 * *$ & $-0.544 * *$ \\
\hline $\mathbf{7}$ & Relative Humidity Average & -0.288 & $-0.649 * *$ & $-0.462^{* *}$ \\
\hline $\mathbf{8}$ & Wind Velocity & $-0.549 *$ & $-0.511 *$ & $-0.518^{* *}$ \\
\hline $\mathbf{9}$ & Cloudy Weather Morning & $-0.653 * *$ & $-0.760 * *$ & $-0.683 * *$ \\
\hline $\mathbf{1 0}$ & Cloudy Weather Evening & $-0.595 * *$ & $-0.786 * *$ & $-0.645^{* *}$ \\
\hline $\mathbf{1 1}$ & Cloudy Weather Average & $-0.629 * *$ & $-0.804 * *$ & $-0.684 * *$ \\
\hline $\mathbf{1 2}$ & Rainy Days & -0.386 & -0.475 & $-0.418^{* *}$ \\
\hline $\mathbf{1 3}$ & Bright Sun-Shine Hours & 0.285 & $0.649 * *$ & $0.475^{* *}$ \\
\hline
\end{tabular}

Note: Critical value (0.05) $2017=+/-0.444^{*} \& 0.561^{* *}, 2018=+/-0.456^{*} \& 0.575^{* *}$ and Pooled $=+/-0.325^{*} \&$ $0.418 * *$

Table.5 Stepwise regression equation for rice false smut on different weather parameters during 2017

\begin{tabular}{|l|c|c|}
\hline $\begin{array}{c}\text { Multiple linear regression equation } \\
\hat{\mathbf{Y}}=\mathbf{a}+\mathbf{b}_{\mathbf{1}} \mathbf{X}_{\mathbf{1}}+\mathbf{b}_{\mathbf{2}} \mathbf{X}_{\mathbf{2}}+\ldots \ldots \ldots \ldots+\mathbf{b}_{\mathbf{n}} \mathbf{X}_{\mathbf{n}}\end{array}$ & $\begin{array}{c}\text { Multiple } \\
\mathbf{R}\end{array}$ & $\begin{array}{c}\text { Co-efficient of determination } \\
\left(\mathbf{R}^{\mathbf{2}}\right)\end{array}$ \\
\hline $\begin{array}{c}\left.\hat{\mathbf{Y}}=\mathbf{- 6 4 . 8 2 6}+\mathbf{1 . 1 5 8}\left(\mathbf{X}_{\mathbf{2}}\right)+\mathbf{0 . 3 7 0}\left(\mathbf{X}_{\mathbf{7}}\right)+\mathbf{( - 0 . 5 1 0}\right) \\
\left(\mathbf{X}_{\mathbf{9}}\right)\end{array}$ & 0.89 & 79.9 \\
\hline
\end{tabular}

Table.6 Stepwise regression equation for rice false smut on different weather parameters during 2018

\begin{tabular}{|c|c|c|}
\hline $\begin{array}{c}\text { Multiple linear regression equation } \\
\hat{\mathbf{Y}}=\mathbf{a}+\mathbf{b}_{\mathbf{1}} \mathbf{X}_{\mathbf{1}}+\mathbf{b}_{\mathbf{2}} \mathbf{X}_{\mathbf{2}}+\ldots \ldots \ldots+\mathbf{b}_{\mathbf{n}} \mathbf{X}_{\mathbf{n}}\end{array}$ & $\begin{array}{c}\text { Multiple } \\
\mathbf{R}\end{array}$ & $\begin{array}{c}\text { Co-efficient of } \\
\text { determination }\left(\mathbf{R}^{\mathbf{2}}\right)\end{array}$ \\
\hline$\hat{\mathbf{Y}}=-\mathbf{4 . 0 8 5}+\mathbf{( - \mathbf { 0 . 5 6 2 } ) ( \mathbf { X } _ { \mathbf { 1 1 } } )}$ & 0.80 & 64.7 \\
\hline Whereas, & $\mathrm{Y}=$ Predicted disease incidence, $\mathrm{X}_{11}=$ Average Cloudy Weather &
\end{tabular}

Table.7 Stepwise regression equation for rice false smut on different weather parameters in pooled

\begin{tabular}{|c|c|c|}
\hline $\begin{array}{c}\text { Multiple linear regression equation } \\
\hat{\mathbf{Y}}=\mathbf{a}+\mathbf{b}_{\mathbf{1}} \mathbf{X}_{\mathbf{1}}+\mathbf{b}_{\mathbf{2}} \mathbf{X}_{\mathbf{2}}+\ldots \ldots \ldots+\mathbf{b}_{\mathbf{n}} \mathbf{X}_{\mathbf{n}}\end{array}$ & $\begin{array}{c}\text { Multiple } \\
\mathbf{R}\end{array}$ & $\begin{array}{c}\text { Co-efficient of } \\
\text { determination }\left(\mathbf{R}^{2}\right)\end{array}$ \\
\hline$\hat{\mathbf{Y}}=-\mathbf{3 5 . 5 8 3}+\mathbf{0 . 7 3 2}\left(\mathbf{X}_{\mathbf{2}}\right)+\mathbf{0 . 1 4 8}\left(\mathbf{X}_{\mathbf{5}}\right)$ & 0.75 & 56.9 \\
\hline
\end{tabular}

Whereas, $\quad \mathrm{Y}=$ Predicted disease incidence,

$\mathrm{X}_{2}=$ Maximum Temperature, $\mathrm{X}_{5}=$ Morning Relative Humidity 
The rainy days, rainfall, maximum temperature $31^{\circ} \mathrm{C}$ and high humidity (90$95 \%$ ) from panicle emerging stage to full heading and flowering stage were favorable conditions for outbreak of rice false smut, these finding corroborate by Jian-Ping et al., (2009), Singh and Pophaly (2010), Kapse et al., (2012), Singh et al., (2012)and Quintana et al., (2016). Bhargava et al., (2018) recorded optimum temperature (31.36 to $\left.23.14^{\circ} \mathrm{C}\right)$, high relative humidity $(88.85$ to $73.50 \%)$, least rainfall $(6.66 \mathrm{~mm})$ and bright sunshine hours (6.20 hrs.) weather condition was more favourable for development of false smut in rice.

In conclusion, it is very clear from the present study that Navsari district is rising area for the rice false smut. The variety GR-11 is grown susceptible. The weather prevailing during kharifis the most congenial favouring the false smut and simultaneously make unprofitable cultivation. Thus, maximum temperature, morning and average relative humidity, morning and average cloudy weather found to play a dominant role in the disease development. Moreover, the work to find out resistant variety, application of balanced fertilizers (especially nitrogen) because the heavy dose of nitrogen it favoured to false smut disease and skip the period of false smut infection, through a change of sowing date, because false smut disease infection initiates at a flowering period during around $2^{\text {nd }}$ week September. The management measures must be taken prior to infection get started to avoid huge losses

\section{References}

Ahonsi, M.O., Adeoti, A. A., Erinle, I. D., Alegbejo, T. A., Singh, B. N. and Sy, A. A. 2000. Effect of variety and sowing date on false smut incidence in upland rice in Edo state, Nigeria. Int. Rice Res.
Notes, 25:14.

Atia, M. M. M. 2004. Rice false smut (Ustilaginoidea virens) in Egypt. J. Plant Dis. Protect., 111:71-82.

Bhargava, P., Kumar, A. and Kumar, S. 2018. Epidemiological studies of false smut disease of rice (Ustilaginoidea virens) in Bihar. J. Pharmacogn. Phytochem., 7(1):1537-1540.

Biswas, A. 2001. False smut disease of rice: a review. Environ. Ecol., 19:67-83.

Devi, T. K. and Singh, N. I. 2007. Aerobiology and epidemiology of false smut disease of rice by Ustilaginoidea virens (Syn. Clariceps oiyzae-satirae) in Thoubal district. Manipur. J. Mycopathol. Res., 45(1):107-108.

Dodan, D. S. and Singh, S. R. 1996. False smut of rice: present status. Agric. Rev., 17(4):227-240.

Fan, J., Guo, Y., Huang, F., Li, Y., Liu, F., Li, L., Xu, Y. J., Zhao, J. Q., Xiong, H., Yu, J. J. and Wang, W. 2014. Epiphytic colonization of Ustilaginoidea virens on biotic and abiotic surfaces implies the widespread presence of primary inoculums for rice false smut disease. Plant Pathol., 63: 937-945.

Gomez, K. and Gomez, A. A. 1984. Statistical procedures for agricultural research, John Wiley and Sons, New York, pp. 680.

Hegde, Y., Anahosur, K. H. and Kulkarni, S. 2000. Chemical control of false smut of rice caused by Claviceps oryzae-sativae Hashioka. Karnataka J. Agric. Sci., 13(3):623-627.

Jian-Ping, L., Tao, T., SongBai, Z. and HeBin, Z. 2009. Preliminary studies on initial infection sources and pathogeninfecting favorable stage for rice false smut. Hyb. Rice, 24(1):74-77.

Kapse, V. V., Bhale, M. S. and Jogi, M. J. 2012. Prevalence of disease in rice in the Jabalpur region. Int. J. Plant Prot., 5(1):16-19. 
Ladhalakshmi, D., Laha, G. S., Singh, R., Karthikeyan, A., Mangrauthia, S. K., Sundaram, R. M., Thukkaiyannan, P. and Viraktamath, B. C. 2012. Isolation and characterization of Ustilaginoidea virens and survey of false smut disease of rice in India. Phytopara., 40: 171176.

Quintana, L., Gutierrez, S., Maidana, M. and Morinigo, K. 2016. Rice false smut [Ustilaginoidea virens (Cooke) Takah.] in Paraguay. Trop. Plant Res., 3(3):704705.

Raji, P., Sumiya, K. V., Dhanya, S., Remya, K. and Narayanankutty, M. C. 2016. Screening of rice varieties and in vitro evaluation of botanicals against false smut pathogen, Ustilaginoidea virens. Int. J. Agric. Sci. Res., 6(2):79-86.

Sanghera, G. S., Ahanger, M. A., Kashayp, S.
C., Bhat, Z. A., Rather, A. G. and Parray, G. A. 2012. False smut of rice (Ustilaginoidea virens) under temperate agro-climatic condition of Kashmir, India. Elixir Bio. Tech., 49: 9827-9830.

Singh, A. K. and Pophaly, D. J. 2010. An unusual rice false smut epidemic reported in Raigarh District, Chhattisgarh. Int. Rice Res. Notes, 35:1-3.

Singh, A. K., Kasana, B. S., Kumar, P. and Singh, B. K. 2012. Occurrence of rice false smut in Bundelkhand region. Int. J. Plant Prot., 5(2): 283-285.

Singh, R. A. and Dubey, K. S. 1978. Assessment of loss in seven rice cultivars due to false smut. Indian Phytopathol., 3: 186-188.

\section{How to cite this article:}

Ankit Kantibhai Chaudhari, Kalubhai Balubhai Rakholiya and Tushar Tersingbhai Baria. 2019. Epidemiological Study of False Smut of Rice (Oryza sativa L.) in Gujarat. Int.J.Curr.Microbiol.App.Sci. 8(06): 2794-2804. doi: https://doi.org/10.20546/ijcmas.2019.806.337 